\title{
Scientific Literacy Among Junior High School Students in Different Curriculum
}

\author{
Yanti Herlanti, Ahmad Soleh \\ Syarif Hidayatullah State Islamic University Jakarta, Jl. Ir. H. Djuanda 95, Ciputat, Indonesia \\ Corresponding e-mail: yantiherlanti@uinjkt.ac.id
}

\begin{abstract}
Indonesia has applied two curricula, namely the former curriculum (2006 - best known as School-Based Curriculum) and the new curriculum (2013 - best known as Content Standard Curriculum) simultaneously since 2014-2017. This study is aimed to determine the student's Scientific literacy on both curricula. The study used survey method which involved 278 students of grade $9^{\text {th }}$ in South Jakarta. Samples were selected by stratified random sampling, including public junior high schools and also madrasah (Islamic junior high school) in upper, middle and lower level. The instrument of TIMSS (Trend International Mathematics Science Study) was adopted and focused on Biology especially reproduction concept. The result showed there was no significant difference in students' scientific literacy on 2006 and 2013 curriculum (Sig 0.236). The scientific literacy was also not known by gender and types of school. Scientific literacy correlates significantly with the students' interest in biology and reproduction.
\end{abstract}

Keywords: Indonesia's curriculum, scientific literacy, reproduction

\section{INTRODUCTION}

Indonesia has developed a new curriculum in 2013. There were 1.521 low secondary schools $(4.16 \%)$ as the pilot project of the new curriculum. However, 95.84 percent schools in Indonesia still implement the former curriculum which is 2006 content standard curriculum. Furthermore, Indonesia has implemented two curricula from 2014 to 2017.

The objective of the new curriculum development, which also includes science subject, is to improve the Indonesian students' literacy. The result of scientific literacy for Indonesian students is not good enough. The Programme for International Student Assesment (OECD PISA) 2009 showed that Indonesian students has reached three among six levels in science. The result on Trend International Matematics and Science Study (TIMSS) in 2007 and 2011 also showed that 95 percent of Indonesian students only reached the medium level (Indonesia Ministy of Education, 2013, 53-55). The result of TIMSS showed that literacy for Indonesian students has decreasing year over year. The National Center Education Statistics (NCES) informed that Indonesia is considered to be the rank 25 with the average score 435 in 1999, ranked 30 with the average score 420 in 2003 , ranked 35 with the average score 427 in 2007 , and ranked 42 with the average score 428 in 2011.

The scientific literacy is very important for the society either they are scientists or not. Science affects almost every aspect of our life, and it will dominates in the future (Shen, 1975, 265). Democracy and future economy will be depending on the literate population (Greenleaf et al, 2011, 648). To judge people of being scientifically literate, proficiency in the discourses of science must be taken into account first. It includes reading, writing, and speaking cognition (Webb, 2010, 448). Therefore, a scientific literacy is described as competitiveness, creativity, and performance in understanding and overcoming social issues (Ogunkola, 2013).

The scientific literacy is different with Math literacy or Computer literacy. Scientific literacy is rarely associated with general thinking skill, but it can 
create educative evaluations on scientific issues and concepts (King, 1983, 6). Experts defines scientific literacy differently. Laugksch $(2000,71)$ summed up 'literacy', which defined by some authors, on three categories, namely learning, competence, and its application to society. A study by De Boer (2000, 519) stated that scientific literacy related to six aspects, i.e. the interrelationships of science and society, the ethics of science, the nature of science, the basic concept of science, science and technology, and the interrelationships of science and humanities.

The institutions which assess and promote scientific literacy also have different definitions. National Science Teaching Association (NSTA) describes that the scientific literacy is an individual abilities of using concept, process, and scientific values in making daily decision. On the other hand, NCES defines scientific literacy as the knowledge and understanding of scientific concepts and processes required for personal decision making, participation in civic and cultural affairs, and economic productivity. Whereas, The Organisation for Economic Co-operation and Development (OECD) defines scientific literacy as the ability to engage with science-related issues, and with the ideas of science, as a reflective citizen.

The study took TIMSS's scientific literacy definition. The assessment of scientific literacy by TIMSS focused on scientific literacy on two dimensions, namely content and cognitive dimensions. The dimension of content consists of four domains, i.e. Biology, Physics, Chemistry, and Geography. Meanwhile, cognitive dimension covers three domains, i.e. understanding facts and procedures or knowledge, employing concept and overcoming routine issues or application, and overcoming non-routie issues or reasoning.

This study is aimed to describe the students' scientific literacy on two different curricula. The writer would like to observe whether any difference in students' scientific literacy between the former curriculum 2006 and new curriculum 2013 and also to explore whether any other factors can affect related to scientific literacy.

\section{METHODS}

This study used a survey method since November to December 2016. The survey was conducted in junior high schools in South Jakarta. There were 72 public junior high schools, 155 private junior high schools, and some Islamic public junior high schools in South Jakarta. The schools which had already implemented 2013 curriculum for three years are 4 public junior high schools , 16 private junior high schools, and 1 Islamic public junior high school. In addition, the study was restricted to public junior high schools which selected based on the stratification, i.e. the school which implement 2013 curriculum and the school which implement 2006 curriculum. The samples for schools which implement 2013 curriculum were a public school and an Islamic public junior hiugh school. Whereas, the sample for schools which implement 2006 curriculum were selected based on the similarity in quality to five public schools which implement 2013 curriculum. One public and Islamic public junior high schools were selected among 32 schools which implement 2006 curriculum and have similarity to 2013 curriculumimplementing schools. The number of students involved in the study are 146 females and 132 males with the average age of 14 years old and are $9^{\text {th }}$ graders.

The scientific literacy competency was observed from the test results on Biology which is in the human reproduction concept. Then, the test questions were developed from TIMSS problems in 2011. The literacy test consisted of of 30 questions comprising 25 items of multiple choice and 5 items of essay. The test contained $60 \%$ knowing, $20 \%$ applying, and $20 \%$ reasoning domain. The test questions were tested on 74 students with validity degree 0.3 and reliability 0.83 .

The factors affecting scientific literacy were seen from the questionnaire of students' perception of Biology and the concept of reproduction. The questionnaire had 30 items with the scale ranges from disagree to agree. The example of questionnaires' statements are "Learning Biology is a fun activity for me", "In my opinion, Biology is easy to understood", and "Learning reproductio system has a lot of benefits for me".

\section{RESULTS AND DISCUSSION}

Based on the numbers of the students who get score less and more than 70, it was proved that there were $37 \%$ students who reach high level score more than 70 . The result is better than the result of TIMSS in 2007 and 2011. According to the result of TIMSS in 2007 and 2011, there were 95\% students who reach medium level $(2014,54)$.

In addition, the numbers of students who reach medium level in 2006 curriculum were greater than in 2013 curriculum. However, the difference of the score was hardly significant. Figure 1 showed that the percentage of students who reach medium level in both curricula. 


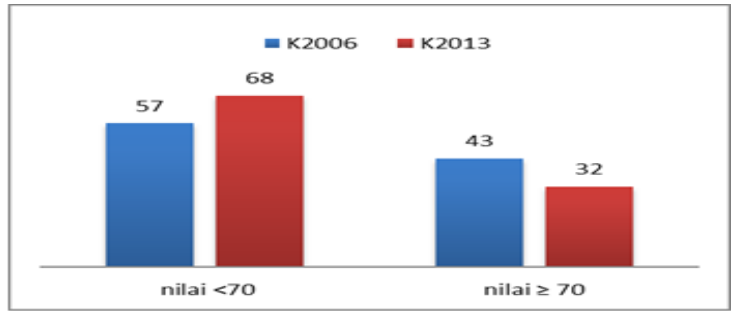

Figure 1. The Percentage of Students Reach High Level of Scientific Literacy (Score more than 70)

Whereas, figure 2 shows the average competence of students' scientific literacy in 2006 curriculum is a bit higher than in 2013 curriclum. However, there is no significant difference $(\mathrm{t}=1.41$ Sig. 0.23$)$ in students' scientific literacy both in 2006 (former) and 2013 (new) curriculum.

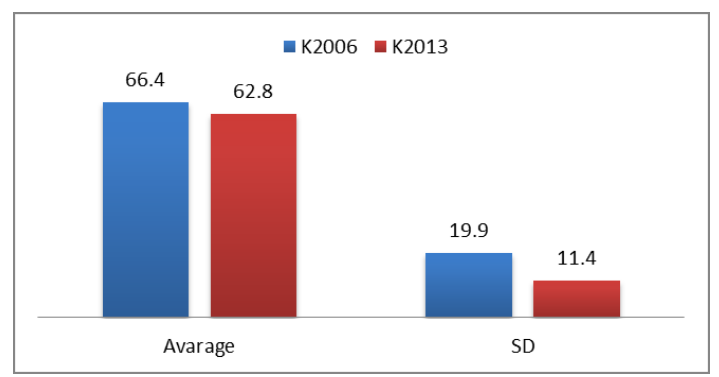

Figure 2. Average and Standard Deviation of Scientific Literacy

On the other hand, Figure 3 shows scientific literacy for each aspect of knowing, applying, and reasoning. Students on the two curriculum has a slight difference. 2013 curriculum is higher in reasoning aspect, meanwhile 2006 curriculum is higher in knowing aspect.

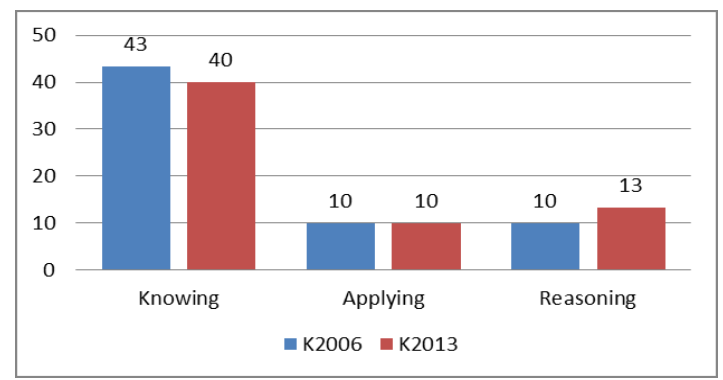

Figure 3. Students' Scientific Literacy Competence on Each Aspect

There is no significant difference on students' scientific literacy in the former and new curricula. There is a little difference on reasoning aspect; however, it is hardly significant. The percentage of students who acquire high level on scientific literacy in the former curriculum is greater than the new curriculum. The difference on the competence in both curricula is shown in Table 1.

Table 1. The Difference on the Competence in both curricula

\begin{tabular}{|c|l|}
\hline $\begin{array}{c}\text { Former Curriculum } \\
(2006)^{*}\end{array}$ & $\begin{array}{c}\text { New Curriculum } \\
(2013)^{* *}\end{array}$ \\
\hline $\begin{array}{c}\text { Describe } \\
\text { reproduction system } \\
\text { and the diseases related } \\
\text { to human reproduction } \\
\text { system. }\end{array}$ & $\begin{array}{l}\text { Understand the } \\
\text { reproduction in plants, } \\
\text { animals and human } \\
\text { being, heredity, and } \\
\text { the survival of living } \\
\text { things. }\end{array}$ \\
\hline
\end{tabular}

*Indonesia Ministry of Education (2006, 383)

**Indonesia Ministry of Education. $(2013,52)$

An analysis which based on the revised Bloom Taxonomy (Karthwohl, 2002, 215) showed that the cognitive dimension could be identified on the use of verbs in basic competence. The verb used in the former curriculum is "describe" and the verb used in the new curriculum was "understand". The word 'describe' in the revised Bloom Taxonomy is similar to explaining. Explaining belongs to cognitive dimension of understanding. The two curricula have similarity on cognitive dimension achievement, i.e. understanding ( $2^{\text {nd }}$ Cognitive). Karhwohl $(2002,216)$ stated that cognitive dimension achievement could be identified from the verbs used. In 2006 curriculum, the nouns used were the reproduction system and diseases. While, in 2013 curriculum, the noun used was reproduction. Therefore, both of the curricula had a similar cognitive dimension achievement, namely conceptual knowledge.

Based on the explanation above, the difference in scientific literacy was not significant between the former and new curriculum in Indonesia because both of curricula had some similar basic competencies to be achieved. The basic competence was used to be the teacher's references in designing various learning objectives, selecting learning methods and media, as well as developing evaluation questions. The achievements of the cognitive dimension and knowledge were similar, so that the teachers could set the similar learning targets in both of curriculas.

Then, the basic competencies demanded in the former and new curricula were still at the level of $\mathrm{C} 2$ (understanding) and K2 (Conceptual Knowledge). Achievements to be achieved is in low order thinking, scientific literacy questions require high-order 
thinking skills. Students are not accustomed to applying higher-order thinking because it is not the achievement of basic competence. Therefore, the ability of scientific literacy in the former and new curriculum lies in the medium level (range of score is 60). It has not been able to reach high level (score more than 70).

Based on the observation, the competency of scientific literacy was not affected by the type of school. There were no significant differences in scientific literacy of students who attending the public junior high schools and Islamic junior high schools (F $=1.47, \mathrm{Sig} 0.22$ ). The scientific literacy competence was also not influenced by the gender. Therefore, there was no significant difference in science literacy between male and female students in the 2006 curriculum ( $F=2.82$ Sig. 0.095) and in the 2013 curriculum $(\mathrm{F}=1.87, \mathrm{Sig} 0.061)$. The competency of scientific literacy is also not related to the age of students. The connection between students' age and the scientific literacy competence was not significantly related $(r=-0.04$, Sig .056).

The competence of scientific literacy was related to students' perceptions of Biology and the concept of reproduction. The relations between students' perception of Biology and scientific literacy showed a positive significant connection $(\mathrm{r}=0.39$, Sig. 0.00$)$. It indicated that the higher the students' interests in Biology, the higher the scientific literacy competence. The relations between learners' perceptions of the concept of reproduction and scientific literacy showed a positive significant connection $(r=0.27, \operatorname{Sig} .03)$. It shows that the more students like the concept of Biology (reproduction), the higher the competence of scientific literacy.

Furthermore, the most influential factor on the students' scientific literacy competence was the perception of students to science and the concept of science. The scientific literacy would be high if the students have a positive perception of science. On the other hand, if learners find science is difficult and stay away from science lessons, the competence of scientific literacy would be low. The results of another research in Indonesia (Ekorahadi, 2014, 39), proved the similar situation. The competence of the scientific literacy is significantly influenced by the students' fondness of science which has contributed on $4.84 \%$. McConney, et al. $(2011,233)$ also found that interest and convenience to science is a supporting factor in the scientific literacy competence.

\section{CONCLUSIONS}

Based on the finding of the research, it could be concluded that there is no significant difference in the competence of students' scientific literacy on the former (2006) and new (2013) curriculas. The students' scientific literacy competence was closely related to students' perceptions of science and the concept of science being studied. Then, the students also had a positive perception of science show good scientific literacy competencies.

\section{ACKNOWLEDGEMENTS}

Thank you to Mr. Mahmud Siregar for some helpful advice on this research.

\section{REFERENCES}

Deboer, G. E. (2000). Scientific Literacy: Another Look at Its Historical and Contemporary Meanings and Its Relationship to Science Education Reform. Journal Of Research In Science Teaching, 37(37), 582-601.

Ekohariadi. (2009). Faktor-faktor yang Mempengaruhi Literasi Sains Siswa Indonesia Berusia 15 Tahun. Pendidikan Dasar, 10(1), 29-43.

Greenleaf, C. L., Litman, C., Hanson, T. L., Rosen, R., Boscardin, C. K., Herman, J., ... Jones, B. (2011). Integrating Literacy and Science in Biology: Teaching and Learning Impacts of Reading Apprenticeship Professional Development. American Educational Research Journal, 48(3), 647-717.

Hufford, T. L. (2016). Oxford University Press, American Institute of Biological Sciences. BioScience, 59(6), 465-469.

Indonesia Ministry of Educaiton. (2014). Workshop Press: 2013 Curriculum Implementation https://kemdikbud.go.id/kemdikbud/dokumen/Papara n/Paparan\%20Mendikbud\%20pada\%20Workshop\% 20Pers.pdf.

Indonesia Ministry of Educaiton. (2013). Based Competence for Low Secondary School.

Indonesia Ministry of Educaiton. (2006). The Indonesia Ministry of Education Rules number 22: Content standard for primary and secondary school.

King, R. C. (1983). Scientific literacy. Change, 15(8), 18 19.

Laugksch, R. C. (2000). Scientific Literacy: A Conceptual Overview. Inc. Sci. Ed, 84, 71-94.

NCES. Trend in International Matematics Science Study. Avalaible online https://nces.ed.gov/timss/

NSTA. (2006). Science and Literacy. Avalaible online www.nsta.org

OECD. The Programme for International Student Assesment. Citing Internet sources URL http://www.oecd.org/pisa/ 
Shen, B. S. P. (1975). Views: Scientific literacy: Public understanding of science is becoming vitally needed in developing and industrialized countries alike. American Scientist, 63(3), 265-268.

Webb, P. (2010). Science Education and Literacy: Imperatives for the Developed and Developing World. Science, 328(5977), 448-450.

Woods-mcconney, A., Oliver, M. C., Mcconney, A., Maor, D., Schibeci, R. (2013). Science Engagement and Literacy: A Retrospective Analysis for Indigenous and Non-Indigenous Students in Aotearoa New Zealand and Australia, Research in Science Education, 233-252. 